\title{
Implementation of Question Answering System by Using the Rule-Based Method About Prophet Muhammad S.A.W.

\author{
Wisnu Uriawan ${ }^{1}$, Ikbar Nur Muhammad ${ }^{2}$, Ichsan Taufik ${ }^{3}$, Cepy Slamet ${ }^{4}$ \\ \{wisnu_u@uinsgd.ac.id'1 ,ikbarrame@gmail.com², ichsan@uinsgd.ac.id ${ }^{3}$, \\ cepy_lucky@uinsgd.ac.id $\left.{ }^{4}\right\}$
} \\ Department of Informatics, UIN Sunan Gunung Djati Bandung, Indonesia ${ }^{1,2,3,4}$
}

\begin{abstract}
Information search is closely related to the need for information. Someone who needs information will think what needed, remember what is need, then decide is what need. Information searching is an activity for human life to find information need. Reading books is one of an effective learning activity to gain knowledge, can get information quickly and easily because just have to open it and start reading. Internet one of the electronic media that provides extensive information for all areas of life. Problems arise due many information contained on internet and difficult of finding the right content, this is certainly not efficient both in terms of time and in terms of the accuracy of the desired answers. The information retrieval system has connection with the search engine. To obtain an best result from search engine is requires input known as queries that are usually as like as of keywords. Search engine system was developed using queries as known as Question Answering System (QAS). By using questions as queries it is expected that the result of information obtained by users more relevant and specific.
\end{abstract}

Keywords: Information, Queries, Question Answering System, Information Retrieval

\section{Introduction}

Information retrieval is closely related to the need for information. Someone who needs information will takes time to think what he needs, remember what he needs, then decide what he do. Information seeking is an activity that cannot be separated from human life to fulfil its information needs [1],[2]. Reading books is one of the effective learning activities to gain knowledge. By reading will can get knowledge more quickly and easily because just choose the book to be read. Therefore, reading should be the main activity of the academic community, especially students. Students are one of the components of the academic community who are demanding knowledge, so reading should be the main agenda of students. Reading will make a one source of inspiration, knowledge source and sharpen students' criticality [3], [4].

Reading activities are essential because reading is the most important for student life and activities. During the learning period students get various messages and information that will determine their moral development and personality. Without learning and direction from the teacher and his parents, it will affect the psychological development of the student. The low reading interest of students will makes student curiosity low. Students right now prefer style or attractive appearance, than improve skills thinking or knowledge [5], [6].

The development of information and communication technology media in the current era shows how more and more communication media are circulating in the community. Now many 
people are turning to using an Smartphone to be used as a medium to access information. This also happened among the students who in the observations of researchers were generations who were adapt to new technologies and new innovations [7]. Information retrieval system has a close relationship with the search engine system. To obtain an information search system requires input known as queries that are usually in the form of keywords. Currently a search system has been developed using queries as queries known as Question Answering System (QAS) [8], [9]. Inspiring Prophet Muhammad S.A.W. is one way to be moral to him. All of this is a logical consequence of the faith in the existence of the Prophet Muhammad S.A.W. as a Messenger. Believing in the Messenger of Allah S.W.T. is believing wholeheartedly that Allah S.W.T. choose among humans to be made his apostles to convey his revelations to mankind $[10]$.

\section{Methodology}

File sharing is an activity where internet users can share data or information with the other users, by uploading data to a server computer and otherwise can download the data from the server computer. Todays, the exchange of data or information is very often done, the possibility of hacking data or information can occur in the exchange of information so that data or information security is needed. The Advanced Encryption Standard algorithm is an algorithm that encodes digital data, specifically document data. doc, .pdf, .txt, .xls, and. ppt. In this study the 128-bit Advanced Encryption Standard (AES) algorithm was implemented to improve security in document data [11], [12], [13].

\subsection{Question Answering System}

Question Answering System is very similar to a search engine. Both allow users for search for information. But there are some differences that distinguish the search engine from question answering system. The most prominent difference is that search engines depend on the user who requests information, not in the form of a question. This request is done by entering a special string in the form of keywords and search engine commands. Output from search engines is usually a set of documents that are according to the user's request, it shown by figure 1. Question Answering System, on the other hand, is asking questions as input and returning specific answers as output [14]. 


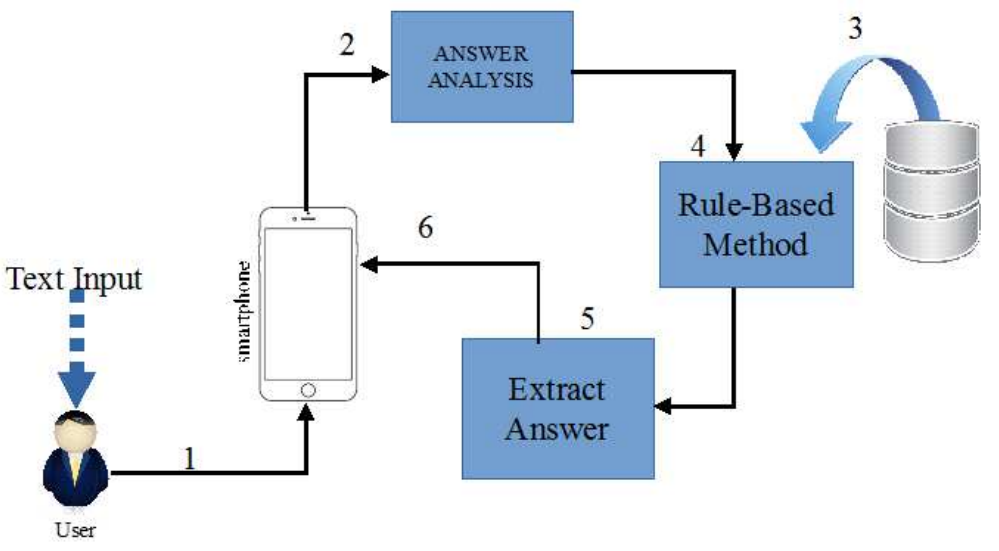

Figure 1. Architecture system

\subsection{Rule-Based System}

Rule-Based System (RBS)[15], [16] is an expert system that uses rules to present its knowledge. rule-based system is a software that presents expertise in the form of rules in a particular domain to solve a problem. RBS is a simple model that can be adapted to many problems. However, if the rules are too many, system maintenance will be complicated and there are many errors. To make RBS, there are some important things you must have: firstly, A set of facts that represent working memory. This can be a situation that is relevant to the initial state of the system working. Secondly, A set of rules. This rule covers every action that must be taken in the scope of the problems needed. Third, Conditions that determine that a solution has been found or not (non-exist) avoid looping without termination [17].

RBS uses a simple technique, starting with the basic rules that contain all the knowledge of the problems faced which are then encoded into if-then rules that contain data, statements and initial information[17], [18]. The system will checks all if conditions rules that determine subset, existing set of conflicts. If found, the system will do the condition then. This loop will continue until one or two conditions are requirement, if the rule is not found, then the system must exit the loop (terminate) [15].

The Relational Unified Process (RUP) recognizes the importance of communication with customers and emphasizes the importance of system descriptions from the customer's point of view (through the use of use case diagrams). RUP emphasizes the importance of the role of software architecture and helps the software architecture to focus on the right targets, such as convenience to understand, bases itself on the possibility of future changes, and also bases itself on component reuse, also suggests an iterative(recurring) process flow and incremental increments, and also enables the implementation of very important evolutionary processes in modern software development [19], [20], [21], it shown by Figure 2. 


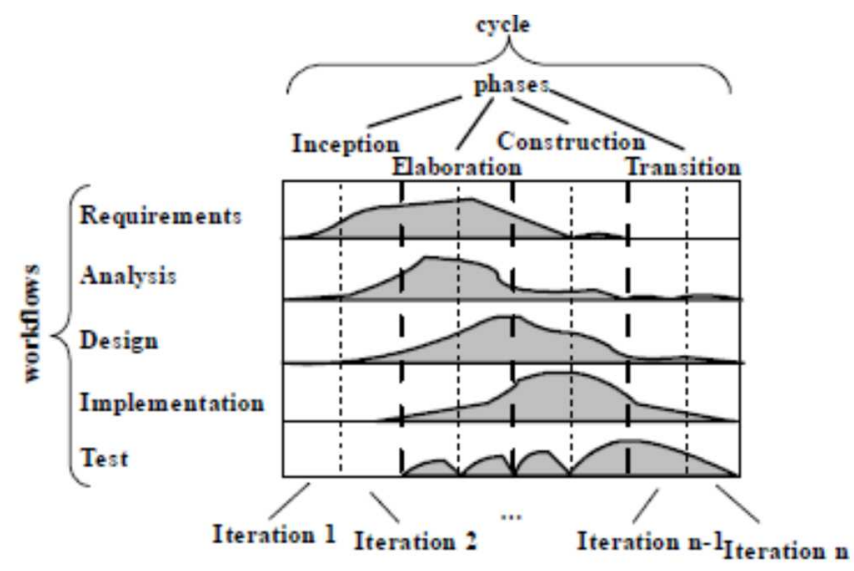

Figure 2. RUP modelling process [20]

\section{Result and Discussion}

\subsection{Use Case Diagram}

In the use case[22] section the diagram explains what can be done by the system to be built and who will interact with the system. Use case diagram becomes user activity. The use case diagram[17] on the system to be built in the following Figure 3:

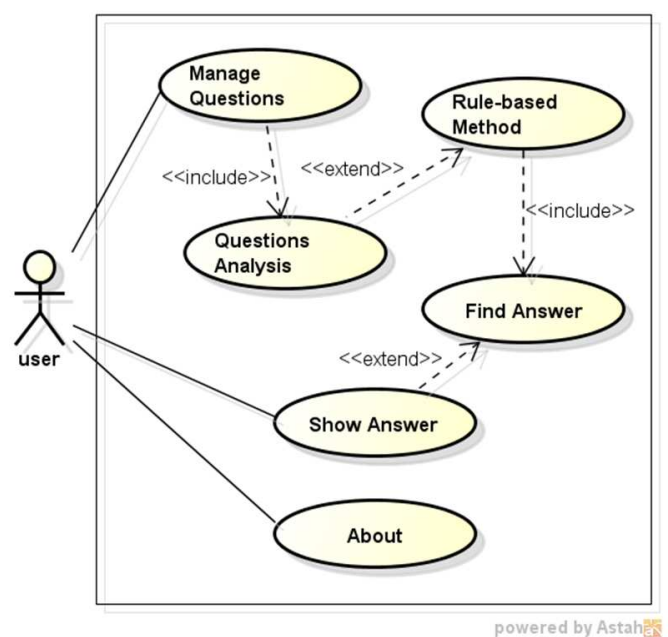

Figure 3. Use case Diagram 


\subsection{Class Diagram}

Class diagrams[23] that are used to model the classes used in the system along with the relationships between classes in the system. Some important elements in class diagrams are classes and relations between classes. As in Figure 4 is a class diagram on a system that was built:

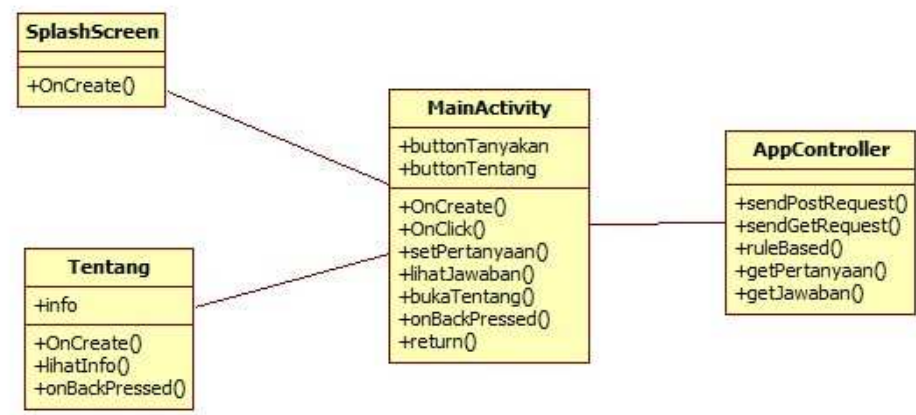

Figure 1. Class Diagram

\subsection{Black Box Testing}

Black-box testing method is a test that focuses on the functional requirements of the software that is built. Below are the stages of functional testing that will be carried out, shown by Table $\mathbf{1}$ :

Table 1. Testing the Use Case Scenario Entering Questions

\begin{tabular}{lccc}
\hline \multirow{2}{*}{ Scenario } & \multicolumn{2}{c}{ Result } & \multirow{2}{*}{ Information } \\
\cline { 2 - 3 } & Success & Failed & \\
\hline Input Question & $\checkmark$ & System accepted \\
\hline
\end{tabular}

In Table 2. the following shows the results of testing a use case scenario analyzing the question:

Table 2. Testing the Use Case Scenario Analyzing Questions

\begin{tabular}{lccc}
\hline \multirow{2}{*}{ Scenario } & \multicolumn{2}{c}{ Result } & Information \\
\cline { 2 - 3 } & Success & Failed & \\
\hline Question & $\checkmark$ & & System accepted regarding Input Question \\
Analysis & $\checkmark$ & & \\
\hline
\end{tabular}

The following Table 3 shows the results of testing the use case scenario to find the answer: 
Table 3. Testing Use Case Finding Scenarios Answers

\begin{tabular}{cccc}
\hline \multirow{2}{*}{ Scenario } & \multicolumn{2}{c}{ Result } & \multirow{2}{*}{ Information } \\
\cline { 2 - 3 } Find Answer & Success & Failed & $\begin{array}{l}\text { System find the answer after analysis the } \\
\text { question }\end{array}$ \\
\hline
\end{tabular}

The following Table 4. shows the results of testing a use case scenario showing the answers:

Table 4. Testing the Use Case Scenario Showing the Answer

\begin{tabular}{cccc}
\hline \multirow{2}{*}{ Scenario } & \multicolumn{2}{c}{ Result } & \multirow{2}{*}{ Information } \\
\cline { 2 - 3 } & Success & Failed & System succeed display the answer \\
\hline Display the Answer & $\checkmark$ & & Systen \\
\hline
\end{tabular}

The following Table 5. shows the results of testing a use case scenario choosing about:

Table 5. Testing the Use Case Scenario Choosing About

\begin{tabular}{lccc}
\hline \multirow{2}{*}{ Scenario } & \multicolumn{2}{c}{ Result } & \multirow{2}{*}{ Information } \\
\cline { 2 - 3 } $\begin{array}{l}\text { Menampilkan } \\
\text { jawaban }\end{array}$ & $\checkmark$ & Failed & $\begin{array}{l}\text { Sistem berhasil menemukkan jawaban } \\
\text { setelah sebelumnya ditemukan. }\end{array}$ \\
\hline
\end{tabular}

Table 6. Below are the stages of functional testing of the Rule-Based Method:

Table 6. Testing of the Rule-Based Method (sampling)

\begin{tabular}{lccc}
\hline \multirow{2}{*}{ Questions } & Time & \multicolumn{2}{c}{ Result } \\
\cline { 3 - 4 } (seconds) & Success & Failed \\
\hline Siapa ayah Nabi Muhammad SAW? & 1.0934 & $\checkmark$ & \\
Siapa ibu Nabi Muhammad SAW? & 0.7668 & $\checkmark$ & $\checkmark$ \\
Siapa paman Nabi Muhammad SAW? & 0.7770 & $\checkmark$ & $\checkmark$ \\
Siapa anak Nabi Muhammad SAW? & 0.8138 & $\checkmark$ \\
Siapa anak pertama Nabi Muhammad SAW? & 1.0567 & $\checkmark$ \\
Siapa anak kedua Nabi Muhammad SAW? & 0.9954 & $\checkmark$ \\
Siapa suami Halimah? & 0.9207 & $\checkmark$ \\
Siapa itu Rahib Bahira? & 1.0267 & $\checkmark$ \\
Siapa istri Nabi Muhammad SAW? & 0.9321 & $\checkmark$ \\
Siapa istri pertama Nabi Muhammad S.A.W? & 1.0354 & $\checkmark$ \\
Siapa istri kedua Nabi Muhammad SAW? & 1.0060 & $\checkmark$ \\
Siapa istri ketiga Nabi Muhammad SAW? & 1.2213 & $\checkmark$ \\
Siapa istri keempat Nabi Muhammad SAW? & 1.3117 & $\checkmark$
\end{tabular}




\begin{tabular}{lccc}
\hline \multirow{2}{*}{ Questions } & Time & \multicolumn{2}{c}{ Result } \\
\cline { 3 - 4 } & (seconds) & Success & Failed \\
\hline Siapa istri kelima Nabi Muhammad SAW? & 1.6501 & $\checkmark$ & \\
Siapa istri keenam Nabi Muhammad SAW? & 1.2397 & $\checkmark$ & \\
Siapa istri ketujuh Nabi Muhammad SAW? & 1.1996 & $\checkmark$ & \\
Siapa istri kedelapan Nabi Muhammad SAW? & 1.2415 & $\checkmark$ \\
Siapa istri kesembilan Nabi Muhammad SAW? & 1.3234 & $\checkmark$ \\
Siapa istri kesepuluh Nabi Muhammad SAW? & 1.1367 & $\checkmark$ \\
Siapa istri kesebelas Nabi Muhammad SAW? & 1.3470 & $\checkmark$ \\
Siapa istri keduabelas Nabi Muhammad SAW? & 1.4403 & $\checkmark$ \\
Siapa itu Abu Lahab? & 1.3847 & $\checkmark$ \\
\hline
\end{tabular}

\subsection{Interface Implementation}

This splash screen page is the first page when users open the Prophet Muhammad S.A.W Question Answer System (QAS) application. this. The display of the page shown by Figure 5 below:

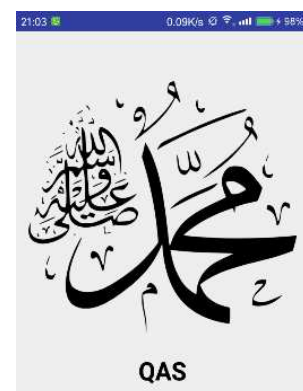

Nabi Muhammad SAW

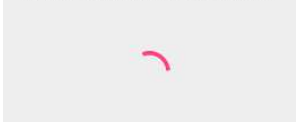

Figure 2. Interface page Splash Screen

In the main page view, the user will enter a question and when the answer is found, the answer will be displayed on this page also. The main page display on the QAS application of the Prophet Muhammad S.A.W. this can be seen in Figure 6 below: 


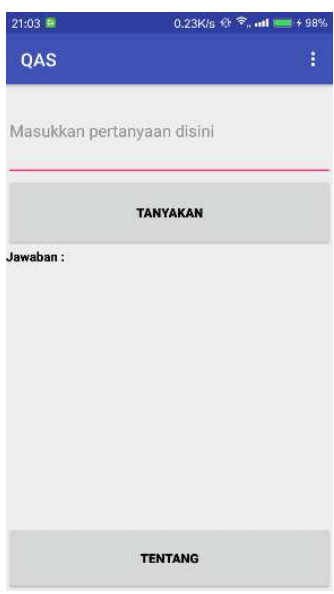

Figure 6. Main Page Interface

This page is a page for displaying information about the application. In it there is also information about the development of the application of the QAS of the Prophet Muhammad S.A.W. this. The page views shown by Figure 7. below:

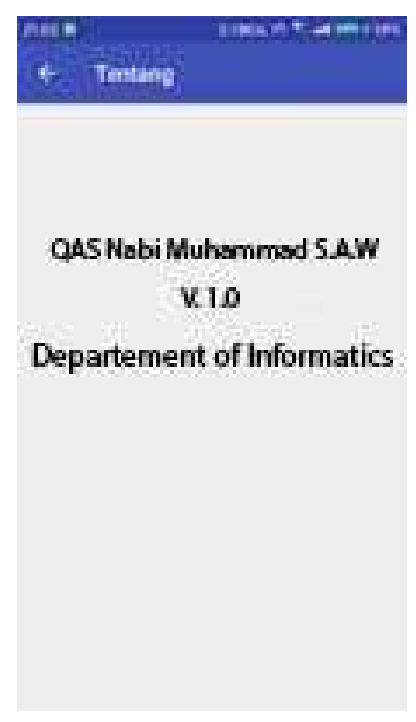

Figure 7. Interface page about 


\section{Conclusion}

Question answering system (QAS) was successfully built on this application about life of family the Prophet Muhammad S.A.W. Android based with The rule-based method applied to the application, is quite effective in discovering relevant answers to the queries given in accordance with the database. Based on the tests that have been carried out with 80 questions in 5 different question categories. From the tests carried out as much as 80 times, it was found that the average time to find an answer was 1.12331625 seconds.

\section{Acknowledgement}

Special thanks for Department of Informatics of UIN Sunan Gunung Djati Bandung that give the full support for our publication research.

\section{References}

[1] A. R. Ilmi, "Perilaku Pencarian Informasi Dengan Menggunakan Media Internet Pada Remaja Awal," pp. 1-16, 2013.

[2] A. Mishra and S. K. Jain, "A survey on question answering systems with classification," J. King Saud Univ. - Comput. Inf. Sci., vol. 28, no. 3, pp. 345-361, 2016.

[3] Deni Hardiyanto, "Studi Tentang Minat Baca Mahasiswa Fakultas Ilmu Pendidikan UNY," vol. 7, pp. 108-121, 2011.

[4] Y. Sharma and S. Gupta, "Deep Learning Approaches for Question Answering System," Procedia Comput. Sci., vol. 132, pp. 785-794, 2018.

[5] M. I. M. Nurhaidah, "Dampak Rendahnyaminat Baca Dikalangan Mahasiswa Pgsd," vol. 3, no. 4, pp. 1-11, 2016.

[6] A. A. S. Gunawan, P. R. Mulyono, and W. Budiharto, "Indonesian Question Answering System for Solving Arithmetic Word Problems on Intelligent Humanoid Robot," Procedia Comput. Sci., vol. 135, pp. 719-726, 2018.

[7] S. R. Juraman, "Pemanfaatan Smartphone Android Oleh Mahasiswa llmu Komunikasi Dalam Mengakses Informasi Edukatif," J. Vol. III. No.1. Tahun 2014, vol. III, no. 1, pp. 116, 2014.

[8] F. Rahmawan, "Implementasi Question Answering System Pada Dokumen Bahasa Indonesia Menggunakan Metode N-Gram," http://repository.ipb.ac.id/jspui/bitstream/123456789/54453/1/G11fral.pdf, 2011.

[9] I. T. Seena, G. M. Sini, and R. Binu, "Malayalam Question Answering System," Procedia Technol., vol. 24, pp. 1388-1392, 2016.

[10] Marzuki, "Meneladani Nabi Muhammad Saw. dalam kehidupan sehari-hari," Humanika, vol. 8, no. 1, pp. 75-87, 2008.

[11] R. J. A. Gentra Muchammad Akbar, Ichsan Taufik, "Implementasi algoritma Advanced Encryption Standard (AES) 128-bit pada aplikasi sharing dokumen berbasis android," INSIGHT, vol. 1, no. 1, pp. 110-115, 2018.

[12] J. BIERNAT, M. CZAPSKI, and M. NIKODEM, Error Correction Procedures for a Hardware Implementation of the Advanced Encryption Standard, vol. 39, no. 17. IFAC, 2006.

[13] D. Natanael, Faisal, and D. Suryani, "Text Encryption in Android Chat Applications 
using Elliptical Curve Cryptography (ECC)," Procedia Comput. Sci., vol. 135, pp. 283-291, 2018.

[14] C. C. Green, "The Application of Theorem Proving to Question-Answering Systems," no. June, 1969.

[15] M. Sasikumar, “A Practical Introduction to Rule Based Expert Systems,” 2007.

[16] N. Talbi, "Design of Fuzzy Controller rule base using Bat Algorithm," Energy Procedia, vol. 162, pp. 241-250, 2019.

[17] P. Ray and A. Chakrabarti, "A Mixed approach of Deep Learning method and RuleBased method to improve Aspect Level Sentiment Analysis," Appl. Comput. Informatics, no. $\mathrm{xxxx}, 2019$.

[18] J. D. McGregor, "Software architecture," J. Object Technol., vol. 3, no. 5, pp. 65-77, 2004.

[19] R. Pressman, "Rekayasa Perangkat Lunak,” Yogyakarta: Andi, 2012.

[20] M. Missikoff and R. Navigli, APPLYING THE UNIFIED PROCESS TO LARGESCALE ONTOLOGY BUILDING Michele Missikoff, Roberto Navigli, vol. 38, no. 1. IFAC, 2005.

[21] S. Galvan, M. Mora, R. V. O’Connor, F. Acosta, and F. Alvarez, "A Compliance Analysis of Agile Methodologies with the ISO/IEC 29110 Project Management Process," Procedia Comput. Sci., vol. 64, pp. 188-195, 2015.

[22] A. J. Stoica, K. Pelckmans, and W. Rowe, "System components of a general theory of software engineering," Sci. Comput. Program., vol. 101, pp. 42-65, 2015.

[23] J. Melegati, A. Goldman, F. Kon, and X. Wang, "A model of requirements engineering in software startups," Inf. Softw. Technol., vol. 109, no. July 2018, pp. 92-107, 2019. 